\title{
Pelatihan Akuntansi Keuangan Lembaga Bagi Guru Smk Dalam Menyiapkan Tenaga Operator Keuangan Desa Dalam Masa Pandemi (MGMP Akuntansi Kota Pekanbaru)
}

\author{
Gusnardi*1, Amir Hasan ${ }^{2}$, Suarman $^{3}$, Nasrizal ${ }^{4}$, RM Riadi $^{5}$ \\ 1,3,5 Pendidikan Ekonomi \\ ${ }^{2,4}$ Fakultas Ekonomi dan Bisnis \\ Universitas Riau \\ email: gusnardi@lecturer.unri.ac.id
}

\begin{abstract}
This service activity is aimed at, among others, 1) provide insight into knowledge about institutional financial accounting, 2) Provide insight into knowledge about the importance of teachers understanding and mastering institutional financial accounting material, 3) Providing skills to develop personnel and knowledge about financial accounting institutions by seeking information related to the material, and 4) Providing provisions for the MGMP Accounting teachers in Pekanbaru City regarding learning models that can be carried out by teachers online, using google classrooms, zoom meetings, google meetings. The method of approach taken to complete this program is by using the lecture, tutorial and discussion method. The training for these teachers was held for 5 days in 5 different vocational schools in Pekanbaru City. From this training, SMK teachers have been able to teach financial accounting for institutions, especially village financial accountants, using online media, so they can use this training as a training tool for the Covid-19 pandemic. It is hoped that the improvement of the skills of vocational school teachers will continue in classroom teaching for institutional financial accounting teaching materials, so that it can produce students or alumni who understand and understand village fund accounting and are expected to become operators or can assist in preparing financial reports in the village.
\end{abstract}

Keywords: financial accounting institutions, village financial operators, during a pandemic

\begin{abstract}
Abstrak
Kegiatan pengabdian ini ditujukan diantaranya; 1) memberikan wawasan pengetahuan tentang akuntansi keuangan lembaga, 2) Memberikan wawasan pengetahuan tentang pentingnya guru-guru memahami dan menguasai materi akuntansi keuangan lembaga, 3) Memberikan bekal kemampuan untuk mengembangkan wawawan dan pengetahuan tentang akuntansi keuangan lembaga dengan mencari informasi berkaitan dengan materi, dan 4) Memberikan bekal kemampuan guru-guru MGMP Akuntansi di Kota Pekanbaru tentang model pembelajaran yang dapat dilakukan oleh guru-guru secara daring, menggunakan google classroom, zoom meeting, google meeting. Metode Pendekatan yang dilakukan untuk menyelesaikan program ini yaitu dengan menggunakan metode ceramah, tutorial, dan diskusi. Pelatihan bagi guru- guru ini dilaksanakan selama 5 hari di 5 SMK yang berbeda di Kota Pekanbaru. Dari pelatihan ini, guru-guru SMK sudah mampu mengajarkan akuntansi keuangan lembaga khususnya akuntan keuangan desa dengan media daring, sehingga mereka dapat memanfaatkan pelatihan ini sebagai sarana pelatihan masa pandemic covid-19 ini. Peningkatan Keterampilan guru-guru SMK ini diharapkan berlanjut dalam pengajaran di kelas untuk materi ajar akuntansi keuangan lembaga, sehingga dapat menghasilkan siswa atau alumni yang paham dan mengerti tentang akuntansi dana desa dan diharapkan bisa menjadi operator atau dapat membantu penyusunan laporan keuangan di desa.
\end{abstract}

Kata Kunci : Akuntansi keuangan lembaga, operator keuangan desa, masa pandemik 


\section{PENDAHULUAN}

Sekolah Menengah Kejuruan merupakan salah satu sekolah terobosan yang dilakukan pemerintah dalam menyiapkan tenaga terampil, hal ini dibuktikannya dengan semakin banyaknya SMK di Propinsi Riau. Persiapan tersebut juga berlaku bagi SMK dengan konsentrasi akuntansi dan keuangan, hal ini sejalan dengan adanya mata pelajaran baru di rumpun keuangan yang selama ini belum pernah di ajarkan yaitu tentang akuntansi keuangan lembaga, sebelumnya mata pelajaran akuntansi di SMK hanya tentang akuntansi keuangan untuk organisasi yang orientasinya untuk bisnis.

Mata pelajaran ini di ajarkan berkaitan dengan terbitnya Undang-Undang Nomor 6 Tahun 2014 tentang desa yang bertujuan memberikan pengakuan dan kejelasan kepada desa akan status dan kedudukannya dalam sistem ketatanegaraan Republik Indonesia, negara memberikan kewenangan desa dalam melestarikan adat dan tradisi serta budaya masyarakat desa.

Desa juga diberikan kewenangan dalam pembangunan untuk memprakarsa dan peran partisipasi yang besar dalam rangka menggali potensi desa dengan mendorong pemerintahan desa yang profesional, efisien dan efektif, terbuka serta bertanggungjawab dalam melaksanakan kegiatan di desa dengan tujuan memberikan pelayanan prima kepada masyarakat yang akhirnya memberikan kesejahteraan bersama dan menempatkan desa sebagai subjek dari pembangunan.

Mata pelajaran akuntansi keuangan lembaga di SMK diajarkan tentang semua proses yang berhubungan dengan transaksi keuangan mulai dari pencatatan, mengklasifikasi jenis transaksi, meringkasnya, mengolah dan menjadikan sebuah data, tujuannya adalah untuk menjadikan sebuah laporan keuangan yang akurat. Selanjutnya digunakan oleh pihakpihak di pemerintahan khususnya di desa sebelum mereka membuat suatu keputusan atau kebijakan.

Ada beberapa permasalahan yang dihadapi oleh guru akuntansi di SMK dalam mengajarkan akuntansi keuangan lembaga ini, diantaranya menurut Gusnardi \& Fenny Trisnawati (2018) bahwa kompetensi guru-guru dalam memahami akuntansi keuangan lembaga masih kurang bila dibandingkan dengan kompetensi mereka dalam mengajarkan akuntansi keuangan yang biasa mereka ajarkan sebelumnya. Hal ini disebabkan mata pelajaran ini merupakan mata pelajar baru, sehingga guru-guru akuntansi harus mengupgrade/ mempelajari lagi materi tentang akuntansi pemerintahan atau akuntansi keuangan daerah dan harus menyesuaikannya dengan silabus mapel akuntansi lembaga/ pemerintah. Permasalahan serupa diungkapkan juga oleh Ketua MGMP Akuntansi di Kota Pekanbaru, bahwa banyak dari guru-guru akuntansi di MGMP masih ragu dan tidak berani dan kalau diperbolehkan memilih mereka akan menunda dulu untuk mengajarkan materi ini. Dari hasil penelitian tersebut guru-guru akuntansi di MGMP Kota Pekanbaru sangat memerlukan pelatihan dan bimbingan dari pakar/ mereka yang ahli dalam bidang akuntansi pemerintahan atau akuntansi keuangan daerah ini. Untuk tingkat SMK materi akuntansi ini dikenal dengan akuntansi keuangan lembaga.

Permasalahan lainnya dalam mengajarkan akuntansi keuangan lembaga terutama dalam masa pandemik coid-19 ini tidak bolehnya melakukan pembelajaran dengan tatap muka, untuk itu pelatihan ini dirancang disamping mengajarkan materi akuntansi keuangan lembaga juga mengajarkan model pembelajaran yang dapat dilakukan oleh guru-guru secara daring, menggunakan google classroom, zoom meeting, google meeting dan lain sebagainya yang dapat dimanfaatkan oleh guru maupun siswa. 
Beragamnya lulusan guru-guru akuntansi yang tergabung dalam MGMP Akuntansi tersebut menimbulkan permasalahan dalam memahami materi akuntansi keuangan lembaga, untuk lulusan pendidikan Ekonomi Akuntansi yang lulus dalam 10 tahun terakhir hal ini tidak menjadi masalah begitu juga untuk lulusan Jurusan Akuntansi dari Fakultas Ekonomi, karena semasa kuliah mereka memang pernah belajar tentang akuntansi keuangan lembaga ini (akuntansi sektor publik/ pemerintahan). Untuk lulusan lainnya yang lulus lebih dari 10 tahun yang lalu mata kuliah atau materi ini sama sekali mereka belum mempelajarinya.

Peran SMK dalam mensukseskan UU tentang desa salah satunya adalah dengan meningkatkan kompetensi guru-guru dibidang akuntansi keuangan lembaga khususnya akuntansi tentang pengelolaan keuangan desa atau lebih dikenal dengan akuntansi dana desa (ADD).

Dalam jangka panjang peran SMK sangat diperlukan karena lulusan SMK di harapkan dapat menjadi tenaga operator dalam pengelolaan dan penyusun laporan keuangan desa. Peluang ini harus dapat diambil oleh guru-guru SMK di Kota Pekanbaru, karena Kota Pekanbaru merupakan Kabupaten terbanyak jumlah SMK di Propinsi Riau setelah Kota Pekanbaru, yakni ada 56 SMK, diantaranya mempunyai jurusan atau bidang keuangan dan bisnis. Dengan jumlah guru bidang akuntansi dan keuangan yang tergabung dalam MGMP Akuntansi Kota Pekanbaru sebanyak 100 orang, diharapkan dapat menghasilkan lulusan dengan penguasaan akuntansi pemerintahan khususnya akuntansi dana desa yang memadai.

Beberapa kegiatan pengabdian dan penelitian terkait dengan pelatihan akuntansi dan kompetensi guru dalam menyiapkan lulusannya telah dilakukan oleh beberapa peneliti, di antaranya oleh Sohidin (2016) menyatakan bahwa pembelajaran dengan menggunakan bahan ajar yang disusun sesuai dengan desain instruksional sangat baik dalam upaya meningkatkan kemampuan mahasiswa. Oleh karena itu, perlu bagi para pengembang materi untuk bisa memahami dan menerapkan desain pembelajaran dalam proses pengembangan paket pembelajaran khususnya praktikum akuntansi.

Penelitian lainnya dilakukan oleh Nurul Widayati (2015) hasilnya lulusan SMK akuntansi tidak hanya sekedar terampil sebagai tenaga akuntan junior saja tetapi juga harus memiliki karakter yang handal dan tangguh yang dapat bersaing dengan tenaga kerja luar negeri. Sedangkan Indah Susilowati dkk (2013) meneliti tentang Strategi Peningkatan Kompetensi Guru dengan Pendekatan Analysis Hierarchy Process dengan kesimpulan bahwa ada 3 hal yang harus dilakukan unruk meningkatkan kompetensi guru yaitu; (1) memilih moralitas calon guru 2) menyaring kualitas guru (3) mengirim guru untuk mengikuti berbagai pelatihan untuk meningkatkan karakter mereka.

Kegiatan pengabdian berkaitan pelatihan akuntansi dan kompetensi guru telah banyak dilakukan oleh tim-tim pengabdi, diantaranya oleh I G.A.M Asri Dwija Putri, dkk (2014). Hasil kegiatan pengabdian mereka menyimpulkan bahwa peserta sangat memahami materi yang diberikan dan bermanfaat untuk menambah wawasan pengetahuan mereka di bidang akuntansi. Para guru dan siswa juga mengharapkan kegiatan semacam ini dapat dilakukan di tahun yang akan datang. Untuk materinya peserta mengharapkan diberikan pengetahuan dibidang akuntansi lainnya seperti akuntansi pajak, akuntansi hotel, akuntansi manajemen dan akuntasi ligkungan.

Kegiatan pengabdian berikutnya dilakukan oleh Nanda Widaninggar dan Nurshadrina Kartika Sari. (2018). Hasil kegiatan mereka menyimpulkan bahwa melalui PKM ini telah berhasil diselesaikan Pelatihan sistem akuntansi dasar dan pelaporan keuangan dan 
pendampingan penerapan program yang berkembang menjadi pembangunan sistem akuntansi berbasis web dengan menghasilkan luaran berupa sistem pelaporan keuangan Aplikasi. Kelemahan suatu aplikasi adalah bahwa compatible atau tidaknya baru bisa diketahui ketika ada masalah. Oleh karenanya pendampingan terus-menerus perlu untuk dilakukan sehingga Aplikasi Akuntansi benar-benar bisa membawa manfaat karena mudah untuk diaplikasikan.

Kemudian Sylvia Christina Daat (2019). Melakukan kegiatan pengabdian tentang Pelatihan Akuntansi Pemerintahan Bagi Guru Akuntansi di Kota dan Kabupaten Jayapura. Hasil kegiatan ini menyimpulkan bahwa bahwa peserta merasakan sangat memperoleh manfaat dari kegiatan yang telah dilakukan.

Kegiatan pengabdian lainnya dilakukan oleh Yumniati Agustin dkk (2019) tentang Pelatihan Penyusunan Laporan Keuangan Bagi Entitas Mikro, Kecil, dan Menengah Bidang Usaha Dagang pada UMKM Binaan Pusat Inkubasi Bisnis Syariah Majelis Ulama Indonesia. Berdasarkan hasil evaluasi melalui kuesioner, tingkat pemahaman peserta dari seluruh materi yang disampaikan, rata-rata mencapai $90 \%$, kecuali tingkat pemahaman materi "Penyajian Laporan Keuangan dan Neraca Saldo Setelah Penyesuaian", dan sebagai rencana tindak lanjut berikutnya adalah membuka forum klinik akuntansi di bawah departemen akuntansi.

Berikutnya kegiatan pengabdian juga telah dilakukan oleh Elisabeth Riupassa dkk (2019), tentang pelatihan komputer akuntansi dengan menggunakan mind your own business pada Jurusan Akuntansi SMK Negeri 6 Ambon. Pelatihan ini menghasilkan bahwa para guru jurusan akuntansi telah memahami dan mengerti Aplikasi MYOB ini sehingga mampu mendidik para siswa tanpa tergantung pada pihak eksternal karena merupakan salah satu kompetensi dalam bidang akuntansi.
Kegiatan pengabdian lainnya dilakukan oleh Yeni Priatna Sari dkk (2020) Saat ini laporan keuangan desa belum mempunyai standar yang ditetapkan oleh Ikatan Akuntan Indonesia. Sehingga saat ini laporan keuangan desa menggunakan aturan yang ditetapkan oleh kementerian dalam negeri saja. Adapun laporan yang dibuat adalah laporan laba rugi, laporan neraca dan laporan realisasi anggaran untuk pemerintah desa. Akuntansi lembaga bukanlah hal baru ketika mempelajari akuntansi keuangan. Hal yang berbeda dari akuntansi lembaga yang telah di ajarkan sebelumnya adalah pada entitasnya serta tidak adanya standar yang telah ditetapkan dari Ikatan Akuntan Indonesia. Sehingga format dan alurnya menjadi tidak seragam dan rancu. Akan tetapi dengan adanya UU No 6 Tahun 2014 tentang dana desa secara bertahap akan dilakukan evaluasi dan bertahap. Seperti akan di sosialisasikannya Standar Akuntansi Pemerintah Desa (SAPDesa) oleh pemerintah.

Dari beberapa kegiatan pengabdian dan penelitian di atas dapat disimpulkan bahwa peningkatan kompetensi guru sangat penting dilakukan, terutama yang berkaitan dengan pelatihan-pelatihan yang mengsikronkan materi ajar disekolah dengan dunia kerja. Untuk rumpun akuntansi dan keuangan di SMK sudah selayaknya guru-guru perlu meningkatkan kompetensinya terutama untuk mata ajar praktik akuntansi keuangan lembaga yang diharapkan lulusannya dapat berperan dalam mensukseskan pelaksanaan dan pelaporan dana desa, yang selama ini dikerjakan oleh perangkat desa. Untuk itu SMK sebagai sekolah kejuruan harus menangkap peluang ini sehingga lulusannya dapat mengisi posisi sebagai operator akuntansi di desa.

Pelatihan yang diberikan ini merupakan solusi bagi guru-guru SMK akuntansi untuk lebih memahami secara mendalam materi akuntansi keuangan lembaga ini, sehingga dapat mengajarkan 
dengan baik kepada siswa-siswanya, dengan harapan dapat menghasilkan lulusan-lulusan akuntansi yang siap pakai. Lulusan SMK ini nantinya dapat mengabdikan ilmunya terutama di desadesa sebagai tennaga operator akuntansi desa, sebagaimana diketahui bahwa pemerintahan tingkat desa sudah wajib membuat laporan keuangan tentang dana desa.

Berdasarkan hal tersebut perlu dilakukan pelatihan atau bimtek bagi guruguru SMK tentang materi pelajaran akuntansi keuangan lembaga khususnya pengelolaan dan penyusunan laporan keuangan dana desa sehingga kompetensi guru-guru dapat meningkat. Peningkatan kompetensi dalam akuntansi lembaga akan berimbas kepada murid-murid yang merupakan out put dari SMK. kegiatan ini telah dilakukan oleh tim pengabdian dan mahasiswa kukerta integrasi Universitas Riau bekerjasama dengan MGMP Akuntansi Kota Pekanbaru.

\section{METODE PENGABDIAN}

\section{Langkah-Langkah Kegiatan}

\section{a. Pembekalan Kuliah Kerja Nyata} (Kukerta) Terintegrasi

Kegiatan pembekalan ini telah dilaksanakan pada tanggal 22 Juni 2020 bertempat di FKIP Universitas Riau. Dalam kegiatan tersebut diadakan diskusi antara DPL dengan mahasiswa Kukerta Terpadu mengenai rencana kegiatan yang akan dilaksanakan, Dosen Pembimbing Lapangan menjelaskan secara rinci tentang program pelatihan terintegrasi. Usai menyimak penjelasan, dilanjutkan sesi tanya jawab. Kemudian, tim pengabdian dan mahasiswa kukerta terpadu merumuskan struktur untuk kegiatan pengabdian. Tak hanya itu, tim pengabdian membagi penanggung jawab dari setiap kegiatan yang dilaksanakan agar lebih fokus dan siap melaksanakan kegiatan tersebut.

\section{b. Survey Lapangan}

Tahapan pertama yang dilakukan tim pengabdian dan mahasiswa kukerta adalah melakukan survey lapangan pertama kali dilakukan pada tanggal 26 \& 27 Juni 2020, Survey ke dua dilakukan tanggal 21 Juni 2019 pukul 9.30 sampai dengan selesai. Survey lapangan dilakukan oleh tim pengabdian dan kukerta terintegrasi bertujuan untuk mengetahui lokasi pelaksanaan kegiatan proker tim kukerta, yang berlokasi di 5 SMK. Mengingat masih mewabahnya pandemic covid-19, kegiatan ini tidak dapat dilaksanakan dengan jumlah peserta yang banyak, maka diambil solusi bahwa pelatihan ini dilakukan di beberapa SMK yang bersedia, diantaranya SMK r SMK Ibta, SMK Saintika, SMKN 6, dan SMK Labor Binaan FKIP Universitas Riau.

Metode pendekatan yang dilakukan untuk menyelesaikan program pelatihan ini dengan menggunakan metode ceramah, tutorial, dan diskusi. Kegiatan yang akan dilakukan adalah penjelasan cara pengelolaan dan penyusunan akuntansi keuangan lembaga khususnya akuntansi keuangan dana desa.

Tahapan kedua adalah tahapan pelaksanaan kegiatan pengabdian. Dalam tahap ini Tim pengabdi melakukan test awal kemampuan guru-guru dalam memahami akuntansi keuangan lembaga sebelum kegiatan pendalaman materi akuntansi keuangan lembaga di berikan. Tahap ke tiga merupakan tahapan yang terakhir adalah tahap evaluasi. Pada tahap ini dilakukan evaluasi atas hasil yang telah dicapai oleh peserta pelatihan. Masukan dan perbaikan lebih lanjut dapat dilakukan pada tahap ini. Evaluasi diberikan dengan memberikan test apakah kemampuan peserta meningkat dengan mengikuti pelatihan tersebut. Kemudian meyimpulkan pemahaman guru-guru akuntansi ketika diberikan materi yang disampaikan dengan metode ceramah dan dilanjutkan dengan tanya jawab/diskusi. 
Adapun sistematika pelaksanaan kegiatan pengabdian ini adalah sebagai berikut:

Langkah 1 (Metode Ceramah):

Peserta diberikan motivasi agar memiliki minat dan motivasi pentingnya materi ini. Selain itu, peserta diberikan materi pentingnya pelaporan keuangan sebagai bentuk pertanggungjawaban.

2. (Metode Tutorial):

Peserta pelatihan diberikan materi bagaimana menyusun laporan keuangan yang memadai sebagai bentuk pertanggungjawaban.

3. Langkah 3 (Metode Diskusi):

Peserta pelatihan diberikan kesempatan untuk mendiskusikan permasalahan yang berkaitan dengan penyusunan laporan keuangan yang selama ini mereka dihadapi.

4. Disamping langkah 1, 2, dan 3 dan di adakan pendampingan dalam menyusun laporan keuangan selama 8 jam dengan jadwal menyesuaikan peserta khalayak sasaran sehingga jumlah jam pengabdian masyarakat terpenuhi.

\section{c. Teknik Penyelesaian Masalah}

Penyelesaian permasalahan

kemampuan guru-guru dalam mengajarkan akuntansi keuangan lembaga terutama dalam masa pandemik ini dilakukan dengan menyelengarakan pelatihan secara terstruktur tentang materi akuntansi keuangan lembaga dengan jadwal dan dapat dilihat pada tabel 1 berikut :

Tabel 2.1

Jadwal Pelatihan Akuntansi Keuangan Lembaga Bagi Guru SMK dalam Menyiapkan Tenaga Operator Keuangan Desa di Kota Pekanbaru

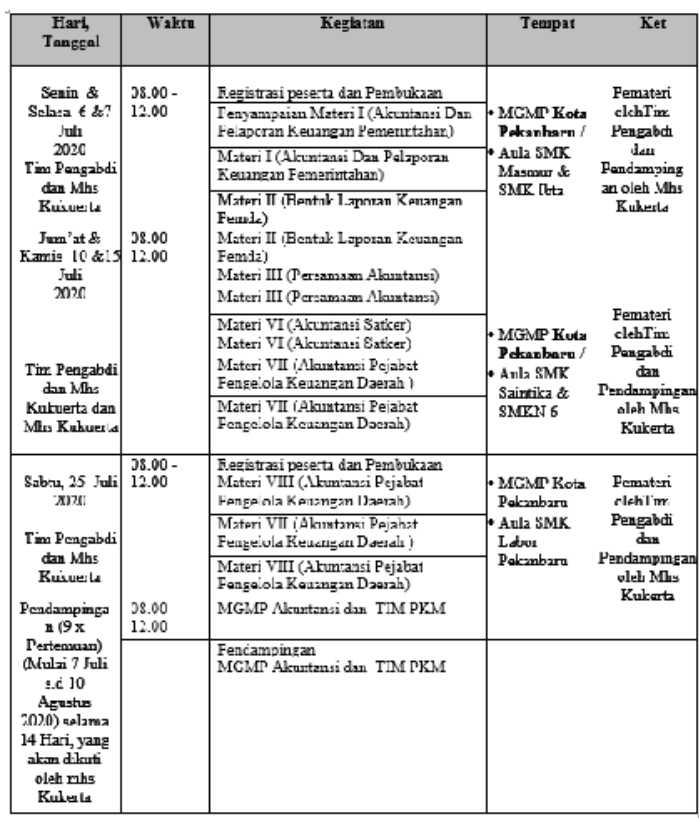

\section{d. Alat Ukur Ketercapaian}

Keberhasilan pelatihan ini dapat di lihat dari respon peserta pelatihan, bahwa mereka sangat antusias mengikuti pelatihan ini karena sebelumnya mereka belum memahami materi ini secara mendalam, terutama tentang pembalajaran akuntansi keuangan lembaga dengan memanfaat media daring. Dengan adanya pelatihan ini guru-guru termotivasi untuk belajar lagi terutama aplikasi materi pembelajaran dengan media online (daring), sehingga walaupun pembelajaran tidak dilakukan dengan tatap muka, guru-guru sedikitnya terbantu dalam menyampaikan materi ke siswa.

\section{HASIL DAN PEMBAHASAN}

\section{a. Gambaran Umum Masyarakat Sasaran}

Peserta pada pelatihan ini adalah Guru SMK yang tergabung dalam MGMK Akuntansi dan keuangan di Kota Pekanbaru sebanyak sebanyak 110 orang dari 20 SMK yang mempunyai rumpun akuntansi dan keuangan. Diharapkan sebahagian besar mereka bisa hadir untuk mengikuti pelatihan ini. Penetapan sasaran ini merupakan suatu upaya peningkatan pemahaman materi dan 
kurikulum akuntansi keuangan lembaga yang merupakan mata pelajaran baru yang di ajarkan di SMK.

Tim pengabdian dalam pelatihan ini di bantu oleh mahasiswa kukerta terintegrasi Universitas Riau. Mengikutkan mahasiswa kukerta ini merupakan program pengabdian dari Universitas Riau bahwa setiap ketiatan pengabdian oleh dosen wajib mengikutsertakan mahasiswa kukerta dengan jumlah 8 sampai 10 mahasiswa

Pelaksanaan kegiatan pelatihan melibatkan beberapa pihak. Terutama guru- guru Akuntansi di Kota Pekanbaru yang sudah mempunyai organisasi yang digunakan sebagai wadah diskusi untuk peningkatan kualitas. Organisasi tersebut adalah Musyawarah Guru Mata Pelajaran (MGMP) Akuntansi. Dengan demikian untuk kelancaran kegiatan tim pengabdi akan bekerjasama dengan MGMP Akuntansi Kota Pekanbaru dalam melaksanakan kegiatan pelatihan ini.

Melalui MGMP diharapkan wawasan pemahaman guru-guru tentang akuntansi keuangan lembaga dapat menyebar lebih luas pada guru-guru akuntansi lainnya yang tidak dapat mendatangi acara pelatihan.

Berhubung kota pekanbaru masih dalam status Bahaya covid-19, acara pelatihan tidak dapat melibatkan sebagian besar guru-guru yang tergabung dalam MGPM tersebut, pelatihan dilakukan dengan melakukan pendekatan dengan beberapa SMK yang mau sebagai tuan rumah tempat pelatihan, dari survey dan pendekatan tersebut disepakati ada 5 SMK sebagai tempat pelatihan dengan jumlah peserta yang terbatas, maksimal per SMK 15 peserta.

\section{Pelatihan di SMK Masmur}

Tempat pelatihan pertama dilakukan di SMK Masmur pada tanggal. 6 Juli 2020, jumlah peserta sebagnyak 14 orang, pelatihan dimulai dengan kata sambutan dari Ka. Prodi Akuntansi SMK Masmur Ibu Mayyanita, S.Pd, dilanjutkan penyampaian protokol kesehatan oleh Mahasiswa Kukerta Intergrasi. Selanjutnya penyampaian materi pelatihan tentang akuntansi keuangan lembaga oleh ketua TIM Pengambdian Dr. Gusnardi, sesi terakhir untuk hari tesebut penyampaian aplikasi materi akuntansi dengan memanfaatkan media dari oleh anggota Tim Pengabdi Universitas Riau oleh Bapak RM Riadi, M.Si.,Ak. Setelah acara selesai disepakati untuk pendampingan pemanfaatan media daring oleh mahasisa kukerta dilakukan pada tanggal. 11 dan 17 Juli 2020 selama 2 hari.

\section{Pelatihan di SMK Ibta}

Pelatihan ke 2 dilakukan di SMK Ibnu taimiyah pada tanggal. 7 Juli 2020, jumlah peserta sebagnyak 15 orang, pelatihan dimulai dengan kata sambutan dari Kepala Sekolah SMK Ibnu Taimiyah, yang sangat merespon kegiatan ini, untuk selanjutnya pihak sekolah terbuka menerima Tim Pengabdi melakukan pengabdian di SMK mereka, selanjutnya dilakukan penyampaian protokol kesehatan oleh Mahasiswa Kukerta Intergrasi dan penyerahan masker serta tempat cuci tangan. Penyampaian materi pelatihan tentang akuntansi keuangan lembaga oleh ketua TIM Pengambdian, sesi terakhir untuk hari tesebut penyampaian aplikasi materi akuntansi dengan memanfaatkan media dari oleh anggota Tim Pengabdi Universitas Riau. Setelah acara selesai disepakati untuk pendampingan pemanfaatan media daring oleh mahasisa kukerta dilakukan pada tanggal. 8 dan 20 Juli 2020, juga dilaksanakan selama 2 hari selain hari pelatihan pertama tadi.

\section{Pelatihan di SMK Saintika}

Pelatihan ke 3 dilakukan di SMK Saintika pada tanggal 10 Juli 2020, jumlah peserta sebagnyak 13 orang, pelatihan dimulai dengan kata sambutan dari Kepala Sekolah SMK Saintika oleh 
Ibu Fitria darma, S.Pd, pihak sekolah sangat merespon kegiatan ini, untuk selanjutnya pihak sekolah terbuka menerima Tim Pengabdi melakukan pengabdian di SMK mereka untuk tahuntahun mendatang. Setelah acara sambutan selanjutnya dilakukan penyampaian protokol kesehatan oleh Mahasiswa Kukerta Intergrasi dan penyerahan masker serta tempat cuci tangan kepada pihak sekolah. Penyampaian materi pelatihan tentang akuntansi keuangan lembaga oleh ketua TIM Pengambdian, sesi terakhir untuk hari tesebut penyampaian aplikasi materi akuntansi dengan memanfaatkan media dari oleh anggota Tim Pengabdi Universitas Riau. Setelah acara selesai disepakati untuk pendampingan pemanfaatan media daring oleh mahasisa kukerta dilakukan pada tanggal 14 dan 15 Juli 2020.

\section{Pelatihan di SMK Negeri 6}

Pelatihan ke 4 dilakukan di SMK Negeri 6 Pekanbaru pada tanggal. 16 Juli 2020, jumlah peserta sebagnyak 13 orang, pelatihan dimulai dengan kata sambutan dari Kepala Sekolah SMK Negeri 6 Pekanbaru oleh Ibu Drs. Hj. Genny Wilyarti.,MM, iihak sekolah sangat berterimakasih dengan adanya kegiatan ini, karena dua hari sebelumnya pihak sekolah baru saja melaksanakan pelatihan pemebelajaran dengan menggunakan media on line untuk semua guru-guru di SMKN 6 tersebut. Selanjutnya pihak sekolah sangat terbuka menerima Tim Pengabdi melakukan pengabdian di SMK mereka, selanjutnya dilakukan penyampaian protokol kesehatan oleh Mahasiswa Kukerta Intergrasi dan penyerahan masker serta tempat cuci tangan. Penyampaian materi pelatihan tentang akuntansi keuangan lembaga oleh ketua TIM Pengambdian, sesi terakhir untuk hari tesebut penyampaian aplikasi materi akuntansi dengan memanfaatkan media dari oleh anggota Tim Pengabdi
Universitas Riau. Setelah acara selesai disepakati untuk pendampingan pemanfaatan media daring oleh mahasisa kukerta dilakukan pada tanggal 21 dan 24 Juli 2020.

\section{Pelatihan di SMK Labor FKIP Univeritas Riau}

Pelatihan ke 5, agak sedikit tersendat untuk menetapkan waktunya, berhubung pihak sekolah masih dalam penrimaan siswa baru, acara pelatihan baru dapat terlaksana pada tanggal 25 Juli 2020 dilakukan di SMK Labor FKIP Universitas Riau, jumlah peserta sebanyak 15orang, pelatihan dimulai dengan kata sambutan dari Kepala Sekolah SMK Labor FKIP Universitas oleh Bapak Drs. Hendripides.,M.Si, pihak sekolah juga sangat merespon kegiatan ini, untuk selanjutnya pihak sekolah terbuka menerima Tim Pengabdi melakukan pengabdian di SMK mereka, selanjutnya dilakukan penyampaian protokol kesehatan oleh Mahasiswa Kukerta Intergrasi dan penyerahan masker serta tempat cuci tangan. Penyampaian materi pelatihan tentang akuntansi keuangan lembaga oleh ketua TIM Pengambdian, sesi terakhir untuk hari tesebut penyampaian aplikasi materi akuntansi dengan memanfaatkan media dari oleh anggota Tim Pengabdi Universitas Riau, untuk materi ini pihak sekolah sudah menerapkankan dalam pembelajaran selama masa covid- 19 ini, Tim Pengabdi hanya menambahkan beberapa topik terkait pembuatan kuiz dan soal bagi siswa secara on line. Setelah acara selesai disepakati untuk pendampingan pemanfaatan media daring oleh mahasisa kukerta dilakukan, dan dilakukan pada tanggal 18 Juli 2020.

\section{b. Potensi Pengembangan}

Kegiatan pelatihan ini sangat diapresiasi terurama oleh guru-guru yang ikut, karena mereka mendapat materi akuntansi keuangan lembaga, juga dapat 
mengaplikasikan materi tersebut dalam pembelajaran daring.

Potensi pengembagan untuk masa mendatang sangat besar, karena guru-guru yang tergabung dalam MGMP akuntansi merupakan guru-guru akuntansi dari berbagai SMK di kota Pekanbaru sangat haus akan ilmu, terutama yang berkaitan dengan akuntansi, ditambah pula dengan aplikasinya dengan media daring.

\section{c. Solusi Pengembangan}

Dari pelaksanaan Pengabdian, tim pengabdian di ditambah mahasiswa kukerta sebagai panitia pelaksana kegiatan dituntut untuk bekerja dalam tim yang didalamnya memiliki kemampuan sosial yang baik, inisiatif, kemampuan belajar dengan cepat, terlatih memahami situasi dan kondisi serta memberikan solusi atas permasalahan yang ada.

Tidak hanya itu, dalam program Pengabdian ini, mahasiswa Kukerta juga harus mengaplikasikan ilmu yang dimilikinya untuk membangun masyarakat sebagai wujud pengabdian intelektual kepada bangsanya.

\section{d. Tingkat Ketercapaian Sasaran Program}

Program dan berbagai kegiatan yang telah dilaksanakan oleh tim pengabdian dan mahasiswa kukerta telah berjalan dengan baik dan mampu mencapai setiap tujuan kegiatan pengabdian tentang pelatihan akuntansi keuangan lembaga dengan media online di 5 SMK di Kota Pekanbaru.

\section{SIMPULAN}

Kegiatan pelaksanaan pengabdian pelatihan akuntansi keuangan lembaga telah terlaksana dengan baik, peserta kegiatan menyatakan bahwa pelatihan ini sangat bermanfaat karena materi pelatihan merupakan bahan pembelajaran baru yang diajarkan di SMK dan ditambah dengan model pembelajarannga dengan menggunakan media online.
Berhasilnya pelaksanaan kegiatan ini diantaranya dapat dilihat dari pernyataan yang dikemukan oleh guruguru bahwa wawasan pengetahuan tentang akuntansi keuangan lembaga meningkat dari sebelumnya, 2) meningkat juga wawasan guru-guru tentang pengetahuan tentang pentingnya guru-guru memahami dan menguasai materi akuntansi keuangan lembaga, 3) bertambahnya bekal kemampuan guru-guru dalam mengembangkan wawasan dan pengetahuan tentang akuntansi keuangan lembaga dengan mencari informasi berkaitan dengan materi tersebut, dan 4) bertambahnya bekal kemampuan guruguru MGMP Akuntansi dalam kegiatan belajar mengajar dengan media on line (daring).

Dengan adanya pelatihan ini guruguru Akuntansi SMK dapat mengajarkan materi tersebut dengan baik ke masing masing siswa mereka dengan harapan lulusannya nanti dapat mengabdikan/ bekerja minimal sebagai tenaga/ operator akuntansi di tingkat desa dimana mereka berada.

Program dan berbagai kegiatan yang telah dilaksanakan oleh tim pengabdian telah berjalan dengan baik yakni pelaksanaan pelatihan akuntansi keuangan lembaga dalam masa covid-19 di 5 SMK di Kota Pekanbaru.

Tim pengabdian dan mahasiswa kukerta terintegrasi telah dapat mencapai tujuan diadakannya program pelatihan ini, yakni dapat membantu guru-guru mengetahui cara dan mengajarkan akuntansi keuangan lembaga yang terintegrasi dengan media daring. Hal ini sangat bermanfaat dalam masa pandemik ini, dimana belajar dan me ngajar tidak dapat dilakukan secara tatap muka antara guru dan siswa.

\section{UCAPAN TERIMAKASIH}

Tim Pengabdian mengucapkan terimakasih yang sebesar-besarnya kepada Rektor Universitas Riau melalui LPPM 
Universitas Riau yang telah mendanai kegiatan pengabdian ini dan dapat dilaksanakan dengan baik dan lancar.

\section{DAFTAR PUSTAKA}

[1] Elisabeth Riupassa, Shella Kriekoff \& Trudy M. Nussy (2019). Pelatihan Komputer Akuntansi Dengan Menggunakan Mind Your Own Business Pada Jurusan Akuntansi Smk Negeri 6 Ambon. Jurnal Pengabdian Masyarakat Jamak (Manajemen \& Akuntansi) Vol 02. No. 02, Desember 2019.

[2] Ernawati, Siswandari, Sohidin, (2016). Pengembangan Bahan Ajar Berbasis Adobe Flash pada Pembelajaran Akuntansi Perusahaan Dagang untuk Meningkatkan Prestasi Belajar Siswa SMK Negeri 1 Surakarta. Jurnal "Tata Arta" UNS, Vol. 2, No. 2 Agustus, 2016, hlm. 1-15.

[3] Gusnardi \& Fenny Trisnawati. (2018). Competence of SMK Teachers Based on Institutional Financial Accounting (SMK State in Pekanbaru). Proceeding of the 2nd URICES, 2018, Pekanbaru, Indonesia P-778-783.

[4] I G.A.M Asri Dwija Putri, dkk.(2014). Sosialisasi pemahaman dan manfaat akuntansi untuk meningkatkan kualitas pembelajaran akuntansi bagi guru dan siswa sma di abiansemal kabupaten badung. Laporan pengabdian kepada masyarakat. Program Studi Akuntansi Fakultas Ekonomi Dan Bisnis Universitas Udayana 2014

[5] IAI KASP (2015). Pedoman Asistensi Akuntansi Keuangan Desa. IAIKASP

[6] Indah Susilowati, Himawan Arif Sutanto, Reni Daharti, (2013). Strategi Peningkatan Kompetensi Guru Dengan Pendekatan Analysis Hierarchy Process. Journal of Economics and Policy. Jejak 6 (1) (2013): 80-92. DOI: 10.15294/jejak.v6i1.37503.
[7] Kementerian Keuangan Republik Indonesia. (2016). Informasi APBN 2017: APBN yang Lebih Kredibel dan Berkualitas di Tengah Ketidakpastian Global. Direktur Jenderal Anggaran. Jakarta.

[8] Nanda Widaninggar dan Nurshadrina Kartika Sari. (2018). Penerapan Sistem Akuntansi Dasar Dan Pelaporan Keuangan KPRI "kencana". Jurnal Pengabdian Masyarakat Ipteks Vol. 4 No.2 Desember 2018 Hal 102- 109 eISSN:2528-116X p-ISSN:2527-5216.

[9] Nurul Widayati, (2015). Optimalisasi Unit Produksi Akuntansi Untuk Pembentukan Karakter Lulusan yang Siap Menghadapi MEA. Prosiding Seminar Nasional Pendidikan Akuntansi dan Keuangan. "Pengembangan Pendidikan Akuntansi dan Keuangan yang Berkelanjutan"

[10] Peraturan Pemerintah Nomor 71 Tahun 2010 tentang Standar Akuntansi Pemerintahan.

[11] Peraturan pemerintah Republik Indonesia Nomor 24 Tahun 2005, tentang Standar Akuntansi Pemerintahan.

[12] Stice , James D, Earl K.Stice, K.Fred Skousen, (2011), Akuntansi Keuangan Intermediate Accounting, Edisi Keenambelas. Diterjemahkan oleh Ali Akbar, Salemba Empat, Jakarta.

[13] Sylvia Christina Daat. (2019). Pelatihan Akuntansi Pemerintahan Bagi Guru Akuntansi Di Kota Dan Kabupaten Jayapura. Jurnal Pengabdian Pada Masyarakat The Community Engagement Journal Volume 2, Nomor 1, Januari-Mei 2019: 35-42 .

[14] Undang-Undang Nomor 23 Tahun 2014 tentang Pemerintah Desa (jo. UU Nomor 2 Tahun 2015 tentang Penetapan Peraturan Pemerintah Pengganti UndangUndang Nomor 2 Tahun 2014 tentang Perubahan atas 
Undang-Undang Nomor 23 Tahun 2014 tentang Pemerintahan Daerah Menjadi Undang-Undang);

[15] Undang-Undang Nomor 23 Tahun 2014 tentang Pemerintah Desa (jo. UU Nomor 2 Tahun 2015 tentang Penetapan Peraturan Pemerintah Pengganti UndangUndang Nomor 2 Tahun 2014 tentang Perubahan atas Undang-Undang Nomor 23 Tahun 2014 tentang Pemerintahan Daerah Menjadi Undang-Undang);

[16] Yeni Priatna Sari , Andri Widianto , Moh Alfian, Ririh Sri Harjanti, Ghea Rahmadiane (2020). Peningkatan Kapasitas Guru Akuntansi Dalam Mata Pelajaran Akuntansi Lembaga (Pelatihan Tata Kelola Keuangan Desa). Jurnal Abdimas PHB Vol 3 No 1 Januari Tahun 2020 p-ISSN:25989030 e-ISSN:2614-056X.I

[17] Yumniati Agustin, Sri Setianingsih , Yudy Dwi Santoso. (2019). Pelatihan Penyusunan Laporan Keuangan Bagi Entitas Mikro, Kecil, dan Menengah Bidang Usaha Dagang pada UMKM Binaan Pusat Inkubasi Bisnis Syariah Majelis Ulama Indonesia. Intervensi Komunitas. Jurnal Pengabdian Masyarakat E-ISSN: 2714-691X OJS: http://ojs.itb-ad.ac.id/index.php/IK. 